\title{
Alterações ao Conselho Executivo da EuChemS a Partir de 2021
}
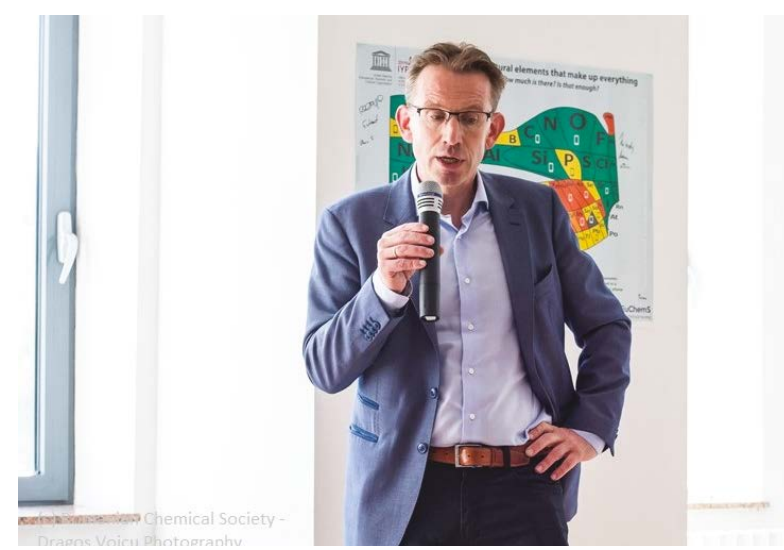

A 1 de janeiro de 2021, o Professor Floris Rutjes (na foto) iniciou o seu mandato de três anos como Presidente da EuChemS, sucedendo à Professora Pilar Goya, que continuará no Conselho Executivo como Vice-Presidente. 0 Professor Floris Rutjes foi Vice-Presidente da Royal Netherlands Chemical Society (KNCV) e Vice-Reitor e Professor da Radboud University na Holanda. Os seus interesses científicos centram-se na área da síntese orgânica, em especial no desenvolvimento de novas e sustentáveis metodologias de síntese, no desenho e síntese de moléculas biologicamente ativas, novas sondas para conjugação bio-ortogonal e química de fluxo contínuo em sistemas de microrreatores. Em 2002, o novo Presidente da EuChems foi premiado com a Medalha de Ouro da KNCV e em 2003 recebeu o Prémio AstraZeneca de Pesquisa em Química Orgânica.

o Conselho Executivo da EuChems também dá as boas-vindas a três recém-chegados: Professora Renáta Oriňaková, Professora Slavica Ražić e Professor Péter Szalay. A EuChemS espera que o renovado Conselho Executivo possa dar início a várias atividades na e para a Química na Europa no futuro, e reitera o seu agradecimento aos ex-membros do Conselho Executivo cujos mandatos terminaram em 31 de dezembro de 2020: Dr. Nausicaa Orlandi, Professor Francisco Javier Pérez Trujillo, Professor Marco Arlorio e Professora Anna Trzeciak.

Bruno Machado

brunofm@fe.up.pt

\section{0: Um Ano para Lembrar ou para Esquecer?}

0 ano 2020 foi realmente muito especial. Contudo, embora muitos prefiram esquecer 2020, para a EuChems foi um ano de grande importância já que assinalou o seu $50{ }^{\circ}$ aniversário! As atividades relacionadas com a celebração deste aniversário, bem como muitos outros projetos e feitos da EuChemS e da sua comunidade, estão compiladas no anuário EuChemS 2020, que agora está disponível online.

0 anuário reflete sobre as iniciativas na área da política científica, faz uma retrospetiva de vários encontros e webinars, considera vários aspetos da comunicação científica e oferece uma visão geral das Redes Profissionais EuChemS e do seu trabalho. Além disso, os vencedores de vários prémios EuChemS são também apresentados, juntamente com as inúmeras atividades e publicações inspiradas na celebração do 50. ${ }^{\circ}$ aniversário da organização desde a sua fundação em

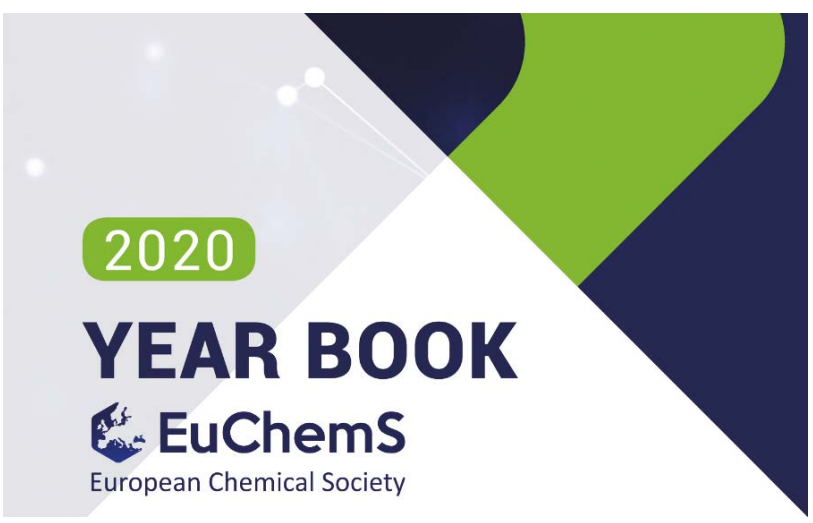

1970 em Praga. Portanto, do ponto de vista da EuChemS, 2020 foi definitivamente um ano para lembrar!

Pode consultar este eoutros anuários da EuChemS em euchems.eu/about-us/year-books.

\section{Bruno Machado}

brunofm@fe.up.pt 